\title{
Pengaruh Kualitas Sistem Informasi, Kualitas Informasi dan Perceived Usefulness terhadap Kepuasan End User Software Akuntansi
}

\author{
Muhammad Raihan Mubaraq1 \\ Fakultas Ekonomi dan Bisnis \\ Universitas Airlangga, Indonesia
}

\author{
Huda Trihatmoko ${ }^{2}$ \\ Fakultas Ekonomi dan Bisnis \\ Universitas Airlangga, Indonesia
}

\begin{abstract}
Surel : mraihanmubaraq@gmail.com
ABSTRAK

Penelitian ini bertujuan untuk memberikan bukti empiris mengenai pengaruh kualitas sistem informasi, kualitas informasi dan perceived usefulness terhadap kepuasan end user software akuntansi. Responden dalam penelitian ini sebanyak 66 responden di 30 SKPD yang berada di Kabupaten Lombok Barat, Nusa Tenggara Barat (NTB) pada divisi akuntansi yang ada di Satuan Kerja Perangkat Daerah yang terlibat langsung dalam penggunaan software akuntansi. Sampel dipilih menggunakan teknik purposive sampling. Teknik pengumpulan data dalam penelitian ini menggunakan metode angket atau kuesioner dengan skala deferensial semantic dan dianalisis menggunakan regresi linier berganda. Hasil penelitian ini menunjukkan bahwa kualitas sistem informasi, kualitas informasi dan perceived usefulness berpengaruh terhadap kepuasan end user software akuntansi.
\end{abstract}

Kata Kunci: Kualitas Sistem Informasi; Kualitas Informasi; Perceived Usefulness; Kepuasan End User.

\section{Effects of Information System Quality, Information Quality and Perceived Usefulness of End User Satisfaction of Accounting Software}

\begin{abstract}
This study aims to provide empirical evidence regarding the effect of information system quality, information quality and perceived usefulness on the satisfaction of end-users of accounting software. Respondents in this study were 66 respondents in 30 SKPDs located in West Lombok Regency, West Nusa Tenggara (NTB) in the accounting division in the Regional Work Unit that is directly involved in the use of accounting software. Samples were selected using a purposive sampling technique. Data collection techniques in this study using a questionnaire or questionnaire with a semantic differential scale and analyzed using multiple linear regression. The results of this study indicate that the quality of information systems, the quality of information and perceived usefulness affect the satisfaction of end users of accounting software.
\end{abstract}

Keywords: Information Systems Quality; Information Quality; Perceived Usefulness; End User Satisfaction.

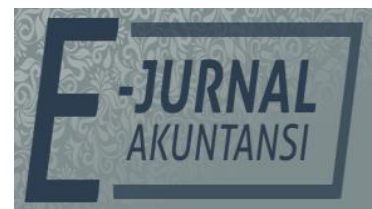

e-ISSN 2302-8556

Vol. 30 No. 10

Denpasar, Oktober 2020

Hal. 2566-2577

DOI:

10.24843/EJA.2020.v30.i10.p10

PENGUTIPAN:

Mubaraq, M. R. \&

Trihatmoko, H. (2020).

Pengaruh Kualitas Sistem Informasi, Kualitas Informasi dan Perceived Usefulness terhadap Kepuasan End User Software Akuntansi. E-Jurnal Akuntansi, 30(10), 2566-2577

RIWAYAT ARTIKEL: Artikel Masuk: 5 Juli 2020 Artikel Diterima: 24 Agustus 2020

Artikel dapat diakses : https://ojs.unud.ac.id/index.php/Akuntansi/index 


\section{PENDAHULUAN}

Kemajuan dibidang teknologi informasi dan komputer pada saat ini dirasa memberikan dampak yang signifikan terhadap berbagai macam informasi. Salah satunya yang ikut berpengaruh adalah perkembangan sistem akuntansi yang ada saat ini mulai berubah menjadi berbasis komputer. Suatu hal menjadi penting dengan perkembangan jaman adalah seseorang dituntut untuk mampu mengikuti dan menguasi teknologi yang ada jika ingin tetap bertahan. Suatu keharusan bagi perusahaan untuk memiliki sistem informasi yang terkomputerisasi satu sama lainnya. Banyak perusahaan yang akhirnya mulai memberikan perhatian khusus untuk dapat mengembangkan teknologi informasi untuk memfasilitasi penggunaan dan sebagai wadah informasi yang efektif dan efisien. Salah satu bentuk perhatian yaitu mulainya menggunakan sistem akuntansi yang berbasis komputer (software akuntansi) agar memudahkan kelancaran arus informasi perusahaan. Kelancaran arus informasi ini sangat dipengaruhi bagaimana software akuntansi ini dijalankan. Pengambilan keputusan yang baik sangat tergantung bagaimana implementasi sistem informasi akuntansi yang telah dibuat sehingga pengawasan pihak internal menjadi lebih efektif dan akhirnya dapat meningkatkan mutu (Sajady et al., 2012).

Diperlukan perencanaan dan strategi yang baik dari seluruh elemen yang berkepentingan untuk dapat paham dan menyesuaikan terhadap perubahan yang muncul sehubungan dengan penerapan model akuntansi baru berbasis akrual. Setiap instansi membutuhkan yang namanya Sistem Akuntansi Instansi (SAI) yang berkaitan dengan konsep akrual, kebijakan pemerintah, dan pemeliharaan sistem aplikasi. Sistem Akuntansi Instansi (SAI) itu sendiri adalah prosedur atau langkah-langkah siklus akuntansi yang diterapkan dalam lingkup kementerian negara atau Lembaga terkait proses transaksi keuangan atau transaksi lainnya yang pada akhirnya menghasilkan laporan keuangan yang memberikan manfaat kepada pihak yang membutuhkan (Kementerian Keuangan Republik Indonesia, 2014).

Sistem Akuntansi Instansi (SAI) merupakan salah satu subsistem dari Sistem Akuntansi Pemerintahan Pusat (SAPP). Hal ini tertuang dalam Peraturan Menteri Keuangan Nomer 171/PMK.05/2007 mengenai Sistem Akuntansi dan Pelaporan Keuangan Pemerintah Pusat. Sistem Akuntansi Instansi (SAI) merupakan prosedur baik secara manual maupun otomastis data transaksi keuangan baik barang atau arus kas yang dimulai dari pengumpulan data sampai dengan hasil akhir pelaporan posisi dan operasi keuangan pada Kementerian Negara. (Peraturan Menteri Keuangan Nomor 171/PMK.05/2007 tentang Sistem Akuntansi dan Pelaporan Pemerintah Pusat, 2007).

Sistem Akuntansi Instansi (SAI) adalah satu contoh dari sistem informasi akuntansi berbasis elektronik atau biasa dikenal EDP (Electronic Data Processing). Sistem ini didesain untuk mengubah data akuntansi yang ada menjadi informasi akhir yang nantinya akan digunakan para end user. Dalam mengoperasikan sistem harus diawasi dan dilakukan dengan hati-hati. Hal ini sejalan dengan yang diungkapkan oleh Hamdan (2012) bahwa sistem akuntansi diciptakan untuk memenuhi kebutuhan instansi dan dapat memberikan kepuasan sehingga dirasa memberikan manfaat untuk meningkatkan kinerja bagi end user. 
Sisi kepuasan pengguna sistem informasi salah satunya dapat dilihat dari berbagai perencanaan dan pengembangan sistem yang nantinya menghasilkan manfaat bagi pengguna. Lee \& Kim (2010) mengungkapkan kepuasan pengguna sebagai rasa puas dan kepercayaan pengguna pada sistem yang ada didalam perusahaan yang menunjang pengguna untuk memenuhi kebutuhannya atau dengan kata lain kesesuaian antara harapan dan apa yang diperoleh. Sistem informasi sendiri telah banyak mengubah organisasi secara luas hingga kedalam proses transaksi dan bisnis. Mutu dan informasi dari sistem merupakan kunci dari keberhasilan kepuasan pengguna yang didasarkan pada harapan dan kebutuhan pengguna. Apabila mutu dan informasi yang disediakan dinilai baik maka akan sesuai dengan keinginan pengguna yang pada akhirnya kesuksesan suatu sistem dapat tercapai. Besar kecilnya pencapaian suatu sistem akan mempengaruhi organisasi.

Hubungan antara kepuasan pengguna dan efektivitas kerja pengguna telah diteliti sebelumnya. Salah satunya adalah penelitian yang dilakukan oleh Rukmiyati \& Budiartha (2016) yang mengatakan bahwa kepuasan pengguna sistem pada umumnya dapat dilhat dari 6 indikator yaitu kelengkapan, stabilitas, kemudahan, inovasi, keamanan dan fleksibilitas. Hal ini menandakan bahwa kepuasan pengguna dapat meningkatkan motivasi untuk mengoptimalkan manfaat sistem yang efektif dan efisien dibidang akuntansi. Hal senada juga dikatakan oleh Fendini et al. (2013), Purnamasari (2015), Pawirosumarto (2016) dan Buana \& Wirawati (2018) bahwa kualitas sistem dan kualitas informasi berpengaruh terhadap kepuasan end user dalam mengoptimalkan manfaat yang dapat menunjang efisiensi.

Model yang dapat digunakan untuk mengukur kualitas sistem dan kualitas informasi adalah model yang dikemukan oleh DeLone \& McLean (2003). Model ini menganggap bahwa kualitas sistem dan kualitas informasi secara sendiri maupun bersama-sama mempengaruhi kepuasan pengguna. Hal ini didukung oleh penelitian Saleh et al. (2012) yang menyatakan hal sama bahwa kualitas sistem sangat dipengaruhi oleh kepuasan pengguna. Hasil penelitian Ali (2016), Rukmiyati \& Budiartha (2016), Zakaria et al. (2017), serta Sujud \& Hachem (2019) juga menyatakan bahwa kualitas sistem informasi memiliki pengaruh terhadap kepuasan pengguna. Berdasarkan hal diatas dapat dikatakan apabila pengguna merasa bahwa sistem informasi memiliki kualitas yang baik, maka pengguna akan merasa puas menggunakan sistem tersebut.

$\mathrm{H}_{1}$ : Kualitas sistem informasi berpengaruh positif terhadap kepuasan end user software akuntansi.

Sistem informasi akuntansi bertujuan untuk memerikan hasil informasi yang dibutuhkan manajer dalam pengambilan keputusan. Kualitas informasi biasanya digunakan untuk mengukur kepuasan pengguna dimana memberikan nilai tambah bagi pemakainya. Kepuasan tersebut dapat dilihat oleh kualitas informasi yang dihasilkan oleh suatu sistem. Suatu sistem dikatakan dapat memuaskan pengguna apabila penggunanya memandang sistem tersebut nyata bukan secara teknik (Tulodo, 2019). Sistem informasi yang optimal akan membawa pengguna merasakan kepuasan dari sistem tersebut. Theory of Reasoned Action (TRA) menjelaskan bahwa sesorang akan akan melakukan perbuatan jika orang tersebut memadang perbuatan. DeLone \& McLean (2003) 
menyatakan bahwa kualitas informasi berpengaruh terhadap kepuasan pengguna. Pernyataan tersebut didukung oleh Ardianto et al. (2014), Kowanda et al. (2016), Ali (2016), dan Rukmiyati \& Budiartha (2016) yang mengatakan bahwa kepuasan pengguna dapat dicapai apabila faktor kualitas informasi dapat dioptimalkan. Berdasarkan hal diatas dapat dikatakan apabila pengguna merasa bahwa kualitas informasi yang dihasilkan baik, maka pengguna akan merasa puas menggunakan sistem tersebut.

$\mathrm{H}_{2}$ : Kualitas informasi berpengaruh positif terhadap kepuasan end user software akuntansi.

Theory of Reasoned Action (TRA) menjelaskan bahwa tindakan seseorang merupakan reaksi dan persepsi seseorang terhadap suatu hal yang nantinya menentukan tindakan dan perilaku seseorang tersebut. Teori ini lebih jauh dikembangkan kedalam model penerimaan teknologi pengguna yang dikenal dengan nama Technology Acceptance Model (TAM) yang digunakan untuk memprediksi penerimaan terhadap teknologi yang didasarkan 2 variabel yaitu persepsi kemudahan (perceived ease of use) dan persepsi kemanfaatan (perceived usefulness) (Fishbein \& Azjen, 1975). Persepsi kemanfaatan (perceived usefulness) didefinisikan sebagai kepercayaan pengguna bahwa pengguna sistem informasi akan dapat meningkatkan kinerja dengan mengunakan sistem yang ada (Kartika et al., 2016). Ardianto et al. (2014) meneliti pengaruh perceived usefulness terhadap kepuasan pengguna. Hasilnya menunjukkan bahwa perceived usefulness berpengaruh terhadap kepuasan pengguna. Penelitian lain juga dilakukan oleh Fong \& Ho (2014) yang meneliti tentang keberhasilan sistem informasi yang baru yang diterapkan di satu organisasi yang mandatory. Hasil dari penelitian Fong \& Ho (2014) menunjukkan bahwa perceived usefulness berpengaruh terhadap kepuasan pengguna. Berdasarkan hal diatas dapat dikatakan apabila pengguna merasakan manfaat atas sistem tersebut, maka pengguna akan merasa puas menggunakan sistem tersebut.

$\mathrm{H}_{3}$ : Perceived Usefulness berpengaruh positif terhadap kepuasan end user software akuntansi.

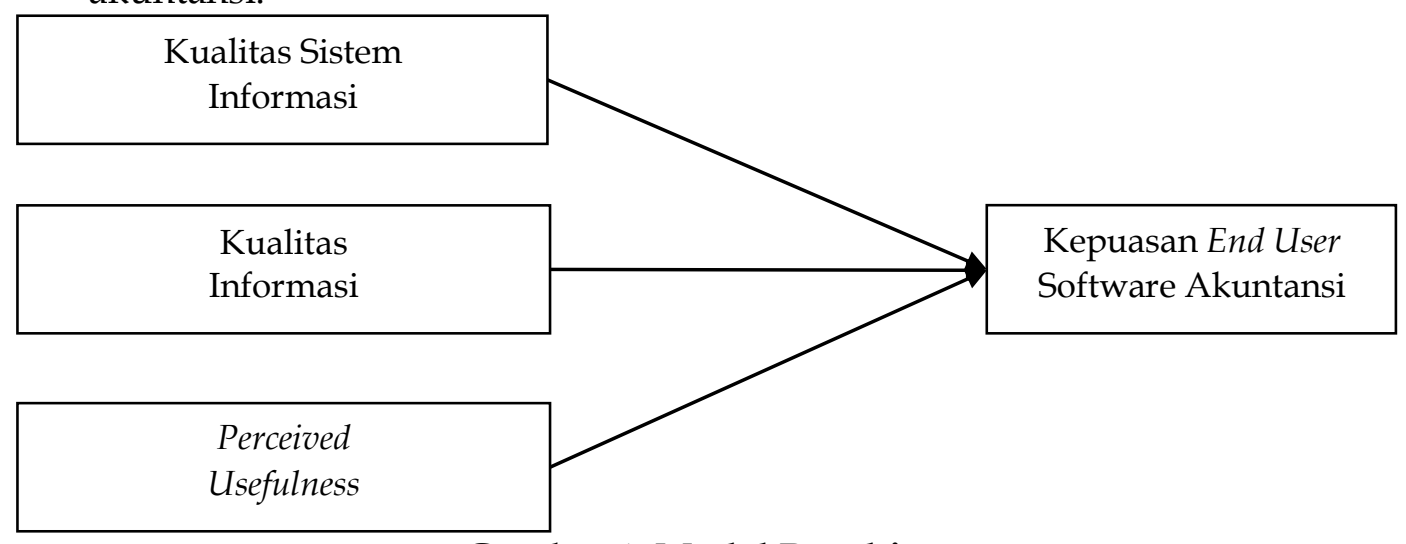

Gambar 1. Model Peneltian

Sumber: Data Penelitian, 2020

\section{METODE PENELITIAN}

Lokasi penelitian yang dipilih adalah Pemerintahan di Kabupaten Lombok Barat, Provinsi Nusa Tenggara Barat (NTB), Indonesia. Kabupaten Lombok Barat 
dipilih karena Kementerian Pendayagunaan Aparatur Negara dan Reformasi Birokrasi (PANRB) pada tahun 2017 memberikan penghargaan kepada Pemerintah Kabupaten Lombok Barat, Provinsi Nusa Tenggara Barat (NTB) atas predikat bagus kategori penataan dan sistematisasi dalam mengimplementasikan Sistem Akuntabilitas Kinerja Instansi Pemerintah (SAKIP). Populasi dalam penelitian ini berada di Kabupaten Lombok Barat pada divisi akuntansi yang ada di Satuan Kerja Perangkat Daerah yang terlibat langsung dalam penggunaan software akuntansi. Sampel dipilih menggunakan teknik purposive sampling.

Kualitas sistem informasi merupakan kualitas sistem yang saat ini digunakan instansi dan berkaitan erat dengan keberhasilan tujuan implementasi (Wisna, 2013). Kualitas sistem informasi yang dimaksud disini adalah kualitas software akuntansi. Kualitas sistem informasi digunakan untuk menjelaskan bahwa performa dari suatu sistem atau kemampuan perangkat baik perangkat keras maupun lunak untuk dapat menyediakan informasi yang dibutuhkan (DeLone \& McLean, 2003). Kualitas sistem informasi dipersepsikan oleh pengguna yang diukur dengan 5 indikator yang digunakan DeLone \& McLean (2003) yaitu kemudahan penggunaan, keandalan sistem, kecepatan akses, fleksibilitas sistem dan keamanan sistem.

Kualitas informasi merupakan kualitas keluaran (ouput quality) dari sistem informasi yang ada yang berupa informasi yang digunakan pengguna dalam penagambilan keputusan (DeLone \& McLean, 2003). Kualitas informasi dipersepsikan oleh pengguna yang diukur dengan 5 indikator yang digunakan DeLone \& McLean (2003) yaitu kelengkapan, bentuk dari keluaran, relevan, akurasi dan ketepatan waktu.

Perceived usefulness atau persepsi kemanfaatan merupakan tingkat kepercayaan pengguna bahwa pengguna sistem informasi akan dapat meningkatkan kinerja dengan mengunakan sistem yang ada (Fong \& Ho, 2014). Perceived usefulness digunakan untuk mengukur tingkat kepuasan pemakai sistem informasi terhadap sistem dan output yang dihasilkan. Variabel perceived usefulness diukur dengan 2 indikator DeLone \& McLean (2003) yaitu manfaat informasi dan manfaat menyeluruh.

Kepuasan end user tercermin dari efektivitas sistem informasi. Efektivitas tersebut merupakan ketepatan menyelesaikan pekerjaan sesuai dengan rencana yang ditelah dibuat (Hla \& Teru, 2015). Kepuasan end user mengukur sejauhmana manfaat penggunaan Sistem Akuntansi Instansi Berbasis Akrual (SAIBA) dalam meningkatan efektivitas kerja pengguna. Efektivitas ini berhubungan dengan tingkat keberhasilan atau kegagalan untuk mencapai tujuan oleh manajemen.

Teknik pengumpulan data yang digunakan adalah metode angket atau kuesioner. Pengumpulan data dengan menggunakan kuesioner ditujukan kepada karyawan bagian software akuntansi keuangan pada Satuan Kerja Perangkat Daerah yang berada di Lombok Barat. Penilaian variabel yang ada menggunakan skala diferensial semantic. Responden dapat memberikan penilaian dengan angka 5 untuk persepsi sangat positif terhadap obyek yang ditanyakan, angka 3 untuk persepsi netral dan angka 1 untuk persepsi sangat negatif terhadap obyek yang ditanyakan. 
Hubungan antara kualitas informasi, kualitas sistem dan perceived usefulness terhadap kepuasan end user dianalisis menggunakan regresi linier berganda dengan persamaan regresi sebagai berikut:

Keterangan :

$$
Y=\alpha+\beta_{1} X_{1}+\beta_{2} X_{2}+\beta_{3} X_{3}+\varepsilon
$$

$$
\begin{array}{ll}
\mathrm{Y} & =\text { Kepuasan end user } \\
\alpha & =\text { Konstanta } \\
\beta_{1}, \beta_{2} & =\text { Koefisien variabel } \\
\mathrm{X}_{1} & =\text { Kualitas sistem informasi } \\
\mathrm{X}_{2} & =\text { Kualitas informasi } \\
\mathrm{X}_{3} & =\text { Perceived usefulness } \\
\varepsilon & =\text { Error }
\end{array}
$$

\section{HASIL DAN PEMBAHASAN}

Responden pada divisi akuntansi yang menggunakan aplikasi Sistem Akuntansi Instasi yang ada di Satuan Kerja Perangkat Daerah (SKPD) yang berada di Kabupaten Lombok Barat berjumlah 30 SKPD dimana masing-masing \pm 2 responden tiap instansi yang terlibat langsung dalam penggunaan software akuntansi dalam mengolah keuangan satuan kerja tersebut sehingga terkumpul $\mathrm{n}=66$ responden dalam penelitian ini. Berikut tabel rata-rata sebaran kuisioner untuk mengetahui rata-rata sebaran tanggapan responden terhadap kuisioner yang disebarkan melalui kategorisasi terhadap rata-rata skor untuk mempermudah menganalisa jawaban responden.

Tabel 1. Hasil Statistik Deskriptif

\begin{tabular}{lccccc}
\hline \multicolumn{1}{c}{ Variabel } & $\mathrm{N}$ & Statements & $\begin{array}{c}\text { Mean } \\
\text { Minimum }\end{array}$ & $\begin{array}{c}\text { Mean } \\
\text { Maximum }\end{array}$ & $\begin{array}{c}\text { Mean } \\
\text { All }\end{array}$ \\
\hline Kualitas Sistem Informasi & 66 & 10 & 3,65 & 4,21 & 3,90 \\
Kualitas Informasi & 66 & 6 & 4,10 & 4,30 & 4,21 \\
Perceived Usefullness & 66 & 6 & 3,84 & 4,18 & 4,00 \\
Kepuasan Pengguna & 66 & 12 & 3,83 & 4,17 & 4,06 \\
\hline
\end{tabular}

Sumber : Data Penelitian, 2020

Berdasarkan Tabel 1, variabel kualitas sistem informasi memiliki nilai rata-rata keseluruhan sebesar 3,90. Nilai ini menunjukkan bahwa responden menjawab pada rentang setuju untuk rata-rata secara keseluruhan. Pernyataan nomor dua merupakan pernyataan yang memiliki nilai tertinggi secara rata-rata sebesar 4,21 yang berisi software akuntansi tersebut memiliki sistem security sehingga pemakai yang tidak berhak, tidak dapat mengakses data yang terdapat di dalamnya, sedangkan rata-rata terendah pada nilai 3,65 yaitu pernyataan nomor 6 yang berisi software akuntansi tersebut dapat digunakan untuk berbagai perusahaan yang karakteristiknya berbeda.

Variabel kualitas informasi memiliki rata-rata keseluruhan sebesar 4,21. Nilai ini menunjukkan bahwa responden menjawab pada rentang sangat setuju untuk rata-rata secara keseluruhan. Pernyataan nomor satu dan tiga memiliki nilai rata-rata tertinggi yang sama sebesar 4,30 yang berisi informasi ketepatan waktu dan keakurasiaan informasi dari hasil software akuntansi yang digunakan, sedangkan rata-rata terendah pada nilai 4,10 yaitu pernyataan nomor 6 yang berisi informasi yang dihasilkan software tersebut mudah dipahami. 
Variabel perceived usefulness memiliki rata-rata keseluruhan sebesar 4,00. Nilai ini menunjukkan bahwa responden menjawab pada rentang setuju untuk rata-rata secara keseluruhan. Pernyataan nomor empat merupakan pernyataan yang memiliki nilai tertinggi secara rata-rata sebesar 4,18 yang berisi penggunaan software akuntansi dapat meningkatkan kinerja, sedangkan rata-rata terendah pada nilai 3,84 yaitu pernyataan nomor satu yang berisi manfaat yang dirasakan pengguna dalam menyelesaikan kebutuhannya dengan lebih cepat dengan bantuan software akuntansi.

Variabel kepuasan pengguna memiliki rata-rata keseluruhan sebesar 4,06. Nilai ini menunjukkan bahwa responden menjawab pada rentang setuju untuk rata-rata secara keseluruhan. Pernyataan nomor delapan merupakan pernyataan yang memiliki nilai tertinggi secara rata-rata sebesar 4,17 yang berisi kejelasan dari informasi yang dihasilkan dari software akuntansi, sedangkan rata-rata terendah pada nilai 3,83 yaitu pernyataan nomor tujuh yang berisi sifat user friendly dari software akuntansi.

Tabel 2. Hasil Regresi Linier Berganda

\begin{tabular}{lrrrrrr}
\hline \multirow{2}{*}{ Model } & \multicolumn{2}{c}{$\begin{array}{c}\text { Unstandardized } \\
\text { Coefficients }\end{array}$} & \multicolumn{2}{c}{$\begin{array}{c}\text { Standardized } \\
\text { Coefficients }\end{array}$} & \multirow{2}{*}{ T } & \multirow{2}{*}{ Sig. } \\
\cline { 2 - 3 } & \multicolumn{1}{c}{ B } & Std. Error & \multicolumn{1}{c}{ Beta } & & \\
\hline (Constant) & 15.311 & 4.349 & & 3.520 & .001 \\
Kualitas Sistem Informasi $\left(\mathrm{X}_{1}\right)$ & .254 & .084 & .269 & 3.022 & .004 \\
Kualitas Informasi $\left(\mathrm{X}_{2}\right)$ & .395 & .138 & .320 & 2.865 & .006 \\
Perceived Usefullness $\left(\mathrm{X}_{3}\right)$ & .563 & .153 & .405 & 3.675 & .000 \\
Adjusted R Square & & .528 & & & \\
Sig. F & & .000 & & & \\
\hline
\end{tabular}

Sumber : Data Penelitian, 2020

Dari hasil regresi linier berganda menggunakan SPSS diperoleh persamaan sebagai berikut.

$$
Y=15,311+0,254 X_{1}+0,395 X_{2}+0,563 X_{3}
$$

Persamaan regresi linear berganda tersebut dapat diketahui bahwa koefisien regresi variabel bebas $(X)$ bertanda positif yang berarti adanya indikasi hubungan yang searah antara variabel bebas $(X)$ dengan variabel terikat $(Y)$. Konstanta $(\alpha)$ bernilai 15,311 berarti jika variabel kualitas sistem informasi $\left(X_{1}\right)$, kualitas informasi $\left(X_{2}\right)$, dan Perceived Usefullness $\left(X_{3}\right)$ nilainya adalah 0 , maka kepuasan pengguna akhir bernilai sebesar 15,311 satuan.

Hasil penelitian ini juga memiliki adjusted $R^{2}$ sebesar 0.528 . Artinya 52,8\% variasi keberhasilan kepuasan pengguna software akuntansi dapat dijelaskan oleh variasi dari ketiga variabel independen yaitu kualitas sistem informasi, kualitas informasi, dan perceived usefulness. Sedangkan sisanya sebesar 47,2\% dijelaskan oleh variabel lain diluar model regresi.

Hipotesis pertama yang diajukan dalam penelitian ini adalah diduga kualitas sistem informasi memiliki pengaruh positif pada kepuasan pengguna akhir software akuntansi. Jika kualitas sistem informasi $\left(X_{1}\right)$ meningkat sebesar $25,4 \%$ dan sebaliknya jika kualitas sistem informasi $\left(X_{1}\right)$ menurun sebesar satu poin maka kepuasan pengguna akhir $(\mathrm{Y})$ menurun $25,4 \%$ dengan asumsi variabel lain dalam keadaan konstan (cateris paribus). Koefisien bernilai positif artinya terjadi hubungan positif antara kualitas sistem informasi dengan kepuasan 
pengguna akhir. Hasil pengujian pada hipotesis pertama ini juga memiliki nilai $t_{\text {hitung }}$ sebesar 3,022 sedangkan nilai $t_{\text {tabel }}$ pada taraf signifikansi $5 \%$ adalah 1,671. Nilai $t_{\text {hitung }}$ pada variabel kualitas sistem informasi lebih besar daripada nilai $t_{\text {tabel }}$ sehingga hasil ini sejalan dengan hipotesis yang telah dirumuskan, oleh karena itu hipotesis pertama diterima.

Hasil penelitian ini sejalan dengan hasil penelitian yang dilakukan oleh DeLone \& McLean (2003) yang menyatakan bahwa kualitas sistem (system quality) dapat mempengaruhi kepuasan pengguna (user satisfaction) didukung pula dengan penelitian yang dilakukan oleh Wisna (2013). Hasil penelitian yang diperoleh Rapina (2014), Fendini et al. (2013), Purnamasari (2015), Pawirosumarto (2016), Kartika et al. (2016), Buana \& Wirawati (2018), Saleh et al. (2012), Ali (2016), Rukmiyati \& Budiartha (2016), Zakaria et al. (2017), Sujud \& Hachem (2019), Hamdan (2012) serta Alnajjar (2017) juga menunjukkan bahwa kualitas sistem informasi berpengaruh positif terhadap kepuasan end user.

Diterimanya hipotesis pertama menunjukkan kualitas sistem informasi yang baik akan menimbulkan rasa puas bagi penggunanya dalam mengunakan software akuntansi tersebut sehingga mampu menghasilkan informasi yang akurat dan efisien sesuai yang diharapkan oleh end user. Kualitas sistem informasi yang andal tersebut tercermin dari kemampuan sistem informasi yang mampu meningkatkan kapasitas pemrosesan data secara signifikan sehingga memudahkan pengguna dalam meminimalisir kesalahan (error) maupun mengoreksi data secara lebih cepat. Rata-rata responden juga sependapat akan lebih mudah menggunakan software akuntansi meskipun berada pada lingkungan organisasi lain sebab tidak banyak yang perlu dimodifikasi.

Hipotesis kedua yang diajukan dalam penelitian ini adalah diduga kualitas informasi memiliki pengaruh positif pada kepuasan pengguna akhir software akuntansi. Jika kualitas informasi $\left(X_{2}\right)$ meningkat sebesar 39,5\% dan sebaliknya jika kualitas informasi $\left(X_{2}\right)$ menurun sebesar satu poin maka kepuasan pengguna akhir menurun 39,5\% dengan asumsi variabel lain dalam keadaan konstan (cateris paribus). Koefisien bernilai positif artinya terjadi hubungan positif antara kualitas informasi dengan kepuasan pengguna akhir. Hasil pengujian pada hipotesis kedua ini juga memiliki nilai thitung sebesar 2,865 sedangkan nilai $t_{\text {tabel }}$ pada taraf signifikansi $5 \%$ adalah 1,671 . Nilai $t_{\text {hitung }}$ pada variabel kualitas informasi lebih besar daripada nilai $t_{\text {tabel }}$ sehingga hasil ini sejalan dengan hipotesis yang telah dirumuskan, oleh karena itu hipotesis kedua juga diterima.

Hasil pengujian ini terkonfirmasi oleh penelitian DeLone \& McLean (2003) bahwa kualitas informasi (information quality) sangat berpengaruh terhadap kepuasan pengguna. Hal senada juga diungkapkan oleh Ardianto et al. (2014). Fendini et al. (2013) yang menyatakan bahwa kualitas informasi (information quality) yang baik setidaknya akan membuat pengguna merasa puas. Purnamasari (2015) dalam penelitiannya menunjukkan bahwa kepuasan pengguna (user satisfaction) sangat tergantung bagaimana kualitas informasi (information quality) yang dihasilkan. Hasil penelitian serupa juga dihasilkan Kowanda et al. (2016), Pawirosumarto (2016), Tulodo (2019), Buana \& Wirawati (2018), Saleh et al. (2012), Ali (2016), serta Rukmiyati \& Budiartha (2016) yang 
menunjukkan bahwa kualitas informasi (information quality) berpengaruh terhadap kepuasan end user.

Diterimanya hipotesis kedua menggambarkan bahwa kualitas informasi yang dihasilkan berupa output informasi bagi kepuasan pengguna memenuhi kriteria akurat, tepat waktu, relevan, mudah dipahami, detail serta benar. Informasi dengan kualitas yang baik dapat digunakan sebagai dasar pengambilan keputusan baik untuk kepentingan saat ini maupun masa yang akan datang. Kualitas informasi yang telah memenuhi unsur tersebut akan mendorong kepuasan pengguna dalam menerima informasi yang dihasilkan.

Hipotesis ketiga yang diajukan dalam penelitian ini adalah diduga perceived usefulness memiliki pengaruh positif pada kepuasan pengguna akhir software akuntansi. Jika perceived usefulness $\left(X_{3}\right)$ meningkat sebesar $56,3 \%$ dan sebaliknya jika perceived usefulness $\left(X_{3}\right)$ menurun sebesar satu poin maka kepuasan pengguna akhir menurun 56,3\% dengan asumsi variabel lain dalam keadaan konstan (cateris paribus). Koefisien bernilai positif artinya terjadi hubungan positif antara perceived usefulness dengan kepuasan pengguna akhir. Hasil pengujian pada hipotesis ketiga ini juga memiliki nilai thitung sebesar 3,675 sedangkan nilai $t_{\text {tabel }}$ pada taraf signifikansi $5 \%$ adalah 1,671 . Nilai thitung pada variabel perceived usefulness lebih besar daripada nilai $t_{\text {tabel }}$ sehingga hasil ini sejalan dengan hipotesis yang telah dirumuskan, oleh karena itu hipotesis ketiga juga diterima.

Sejalan dengan penelitian yang dilakukan oleh Ardianto et al. (2014) yang melihat hubungan antara kepuasan end user dengan perceived usefulness dengan menggunakan yang dikembangkan dan disempurnakan oleh DeLone \& McLean (2003) yang menunjukkan bahwa perceived usefulness berpengaruh terhadap kepuasan end user. Kartika et al. (2016), Tulodo (2019), Buana \& Wirawati (2018), Rukmiyati \& Budiartha (2016) dan Fong \& Ho (2014) juga melakukan penelitian yang serupa dimana mendukung bahwa perceived usefulness berpengaruh terhadap kepuasan end user. Sehingga apabila pengguna merasakan manfaat atas sistem terbut, maka pengguna akan merasa puas menggunakan sistem tersebut.

Diterimanya hipotesis ketiga menunjukkan bahwa perceived usefulness dalam penggunaan sistem informasi dapat meningkatkan kinerja pengguna software akuntansi tersebut. Hal ini juga akan mampu meningkatkan produktivitas kerja dari pengguna sistem informasi sebab dapat memudahkan pengguna dalam menjalankan tugasnya agar lebih efektif misalkan didukung dengan tingkat akurasi sistem informasi yang bersifat user friendly dalam menghasilkan informasi sesuai dengan format yang dibutuhkan. Tentunya informasi yang dihasilkan akan sangat membantu dalam memenuhi perceived usefulness bagi penggunanya.

\section{SIMPULAN}

Tanpa disadari teknologi berkembang dengan sangat cepat. Perkembangan ini tercipta karena adanya sistem yang baik yang pada akhirnya memudahkan penggunanya untuk menggunakannya sesuai dengan kebutuhan yang diharapkan. Sistem yang baik tentunya sangat tergantung bagaimana kualitas sistem informasi, kualitas informasi maupun perceived usefulness dapat membantu end user merasa puas telah menggunakan sistem tersebut. 
Hasil penelitian ini menunjukkan kualitas sistem informasi memiliki pengaruh terhadap kepuasan end user software akuntansi. Dimana apabila pengguna merasa bahwa sistem informasi memiliki kualitas yang baik, maka pengguna akan merasa puas menggunakan sistem tersebut. Kualitas informasi memiliki pengaruh terhadap kepuasan kepuasan end user software akuntansi. Dimana apabila hasil dari sistem dirasa lebih optimal maka akan membuat pengguna merasa puas menggunakan sistem tersebut. Perceived usefulness memiliki pengaruh terhadap kepuasan end user software akuntansi. Dimana apabila pengguna merasakan manfaat atas sistem tersebut, maka pengguna akan merasa puas menggunakan sistem tersebut.

Penelitian ini memiliki keterbatasan salah satunya hanya mengukur faktor-faktor penenetu keberhasilan sistem informasi dengan menggunakan Technology Acceptance Model (TAM) dan DeLone and McLean Model of Information System Success (DEM IS Success). Artinya masih banyak model dan variabel lain yang dapat digunakan untuk memperluas objek penelitian seperti mempertimbangkan faktor-faktor ekternal misalnya adanya sistem pengendalian internal yang sekiranya dapat menggambarkan kepuasan pengguna sistem informasi akuntansi di satuan kerja perangkat daerah.

\section{REFERENSI}

Ali, B. J. A. (2016). The Critical Success Factors of Accounting Information System (AIS) and It's Impact on Organisational Performance of Jordanian Commercial Banks. International Journal of Economics, Commerce and Management, 4(4), 658-677.

Alnajjar, M. I. M. (2017). Impact of Accounting Information System on Organizational Performance: A Study of SMEs in the UAE. Global Review of Accounting and Finance, 8(2), 20-38.

Ardianto, G., Fauziati, S., \& Nugroho, E. (2014). Faktor-Faktor Yang Mempengaruhi Kepuasan Pengguna Akhir Sistem Informasi Sumber Daya Manusia (Studi Kasus di BPK RI). Seminar Nasional Teknologi Informasi Dan Multimedia, 2(1), 29-34.

Buana, I. B. G. M. M., \& Wirawati, N. G. P. (2018). Pengaruh Kualitas Sistem Informasi, Kualitas Informasi, dan Perceived Usefulness Pada Kepuasan Pengguna Sistem Informasi Akuntansi. E-Jurnal Akuntansi Universitas Udayana, 22(1), 683-713.

DeLone, W. H., \& McLean, E. R. (2003). The DeLone and McLean model of information systems success: A ten-year update. Journal of Management Information Systems. https:/ / doi.org/10.1080/07421222.2003.11045748

Fendini, D. S., Kertahadi, \& Riyadi. (2013). Pengaruh Kualitas Sistem Dan Kualitas Informasi Terhadap Kepuasan Pengguna (Survei Pada Karyawan Pengguna Aplikasi Pelayanan Pelanggan Terpusat (AP2T) di PT. PLN (Persero) Area Malang). Jurnal Administrasi Bisnis, 4(1), 1-11.

Fishbein, M., \& Azjen, I. (1975). Belief, Attitude, Intention, and Behavior: An Introduction to Theory and Research. Reading, MA: Addison-Wesley. Contemporary Sociology.

Fong, S. C. C., \& Ho, M. W. H. (2014). Accounting Information Systems End-User Satisfaction: Evidence of Hong Kong Housing Authority. The International 
Technology Management Review, 4(1), 27-41.

Hamdan, M. W. (2012). The Impact of Accounting Information Systems (AIS) Development Life Cycle on its Effectiveness and Critical Success Factors. European Scientific Journal, 8(6), 19-32.

Hla, D., \& Teru, S. P. (2015). Efficiency of Accounting Information System and Performance Measures - Literature Review. International Journal of Multidisciplinary and Current Research, 3(1), 976-984.

Kartika, N. D., Anton, \& Adnanti, W. A. (2016). Analisis Kualitas Sistem Informasi, Perceived Usefulness dan Kualitas Informasi Terhadap Kepuasan End User Software Akuntansi. Simposium Nasional Akuntansi XIX, Lampung, $1-21$.

Kementerian Keuangan Republik Indonesia. (2014). Modul Sistem Akuntansi Pemerintah Pusat (SAPP). Jakarta: Kementerian Keuangan.

Kowanda, D., Firdaus, M., \& Pasaribu, R. B. F. (2016). Determinan Kepuasan Pengguna Akhir Aplikasi ERP Free Open Source Adempiere Pada Usaha Kecil Menengah: Studi Kasus Pada UKM Blessings. Jurnal Riset Akuntansi Dan Keuangan Fakultas Bisnis UKDW, 12(2), 111-129.

Lee, H. S., \& Kim, J. W. (2010). Student User Satisfaction with Web-based Information Systems in Korean Universities. International Journal of Business and Management, 5(1), 62-68.

Pawirosumarto, S. (2016). Pengaruh Kualitas Sistem, Kualitas Informasi, dan Kualitas Layanan terhadap Kepuasan Pengguna Sistem E-Learning. MIX: Jurnal Ilmiah Manajemen, 6(1), 419-433.

Purnamasari, R. (2015). Pengaruh Kualitas Sistem Informasi Akuntansi Terhadap Kualitas Informasi Akuntansi Dan Implikasinya Pada Kepuasan Pengguna Akhir (Studi Kasus Pada PT. PLN (Persero) Distribusi Jawa Barat dan Banten). Jurnal Universitas Komputer Indonesia, 1-25.

Rapina. (2014). Factors Influencing the Quality of Accounting Information System and Its Implications on the Quality of Accounting Information. Research Journal of Finance and Accounting, 5(2), 148-154. https:// doi.org/10.1017/CBO9781107415324.004

Peraturan Menteri Keuangan Nomor 171/PMK. 05/2007 tentang Sistem Akuntansi dan Pelaporan Pemerintah Pusat, (2007).

Rukmiyati, N. M. S., \& Budiartha, I. K. (2016). Pengaruh Kualitas Sistem Informasi, Kualitas Informasi dan Perceived Usefulness pada Kepuasan Pengguna Akhir Software Akuntansi (Studi Empiris Pada Hotel Berbintang di Provinsi Bali). E-Jurnal Ekonomi Dan Bisnis Universitas Udayana, 5(1), 115142.

Sajady, H., Dastgir, M., \& Nejad, H. H. (2012). Evaluation of the effectiveness of accounting information systems. International Journal of Information Science and Management (IJISM), 6(2), 49-59.

Saleh, T., Darwanis, \& Bakar, U. (2012). Pengaruh Kualitas Sistem Informasi terhadap Kualitas Informasi Akuntansi dalam Upaya Meningkatkan Kepuasan Pengguna Software Akuntansi pada Pemerintah Aceh. Jurnal Akuntansi Pascasarjana Universitas Syiah Kuala, 1(1), 110-124.

Sujud, H., \& Hachem, B. (2019). Effect of the Quality of the Accounting Information System Outputs on Customer Satisfaction in Lebanese 
Commercial Banks. International Research Journal of Finance and Economics, 176, 26-40.

Tulodo, B. A. R. (2019). Analisis Pengaruh Kualitas Sistem, Kualitas Informasi dan Perceived Usefulness terhadap Kepuasan Pengguna Aplikasi Care dalam Upaya Peningkatan Kinerja Karyawan. Jurnal Riset Manajemen Sains Indonesia, 10(1), 25-43.

Wisna, N. (2013). The Effect of Information Technology on the Quality of Accounting Information system and Its impact on the Quality of Accounting Information. Research Journal of Finance and Accounting, 4(15), 69-75.

Zakaria, W. Z. W., Ilias, N., \& Wahab, N. (2017). A Survey on the Impact of Accounting Information System on Tasks Efficiency: Evidence from Malaysian Public Sector Agencies. International Review of Management and Marketing, 7(1), 183-190. 